Јелена Јочић

Универзитет у Београду

Филолошки факултет

Катедра за славистику

jelenaradovanovic9@gmail.com
УДК 811.161.1'373.7:811.163.41'373.7

https://doi.org/10.18485/slavistika.2021.25.2.11

Оригиналан научни рад примљено 19.7.2021.

прихваћено за штампу 6.10.2021.

\title{
НЕСИНОНИМСКЕ ЛЕКСИЧКЕ ВАРИЈАНТЕ КОМПОНЕНАТА ЧЁРТ И ВРАГ У РУСКИМ И СРПСКИМ ФРАЗЕОЛОГИЗМИМА
}

У овом раду бавићемо се анализом лексичких варијанти компонената чёрт и враг у 56 фразеологизама ексцерпираних из фразеолошких речника руског и српског језика. Лексичке варијантне компоненте могу бити синоними, али не нужно. Наш фокус биће усмерен ка оним варијантним компонентама које нису синоними лексема чёрт и враг. Ове компоненте биће анализиране на лексикографском, лексиколошком, етимолошком, фразеолошком и лингвокултуролошком плану. Циљ рада јесте утврђивање сличности и разлика у фразеологији двају контрастираних сродних језика, као делу језичке слике света.

Кључне речи: фразеологија, варијантност, лексичка варијантна компонента, руски, чёрт, српски, враг

In this paper, we analyse lexical variant components of the word чёpm and враг (Engl. devil) in 54 idioms and fixed expressions excerpted from phraseological dictionaries of Russian and Serbian. Lexical variant components may be synonyms of the words they are replacing, but not necessarily. Our focus is directed at those variant components that are not synonyms of the lexemes чёpm and spaz (Engl. devil), i.e. that are not recorded by the dictionaries of synonyms of the Russian and Serbian languages. These components are analysed on the lexicographic, lexicological, etymological, phraseological and linguoculturological levels. The aim of this paper is to determine the similarities and differences in the phraseology of two contrasted cognate languages, as part of a linguistic view of the world.

Keywords: phraseology, variation, lexical variant component, Russian, чёрm, Serbian, враг, (Engl. devil).

Питање могућности издвајања фразеолошких варијанти представљало је један од каменова спотицања међу фразеолозима. Поједини фразеолози (Бертагаев, Зимин 1960; Коваленко 1969; Мокиенко 1989: 9-48; Сидоренко 1964; Шанский 1985; Шкляров 1962, 1967) сматрају да замена једне компоненте, па макар и синонимом, мења карактер унутрашње форме фразеологизма и „создает другую фразеологическую единицу, синонимичную первой” (Федоров 1973: 135). С њихове тачке гледишта појам фразеолошке варијанте могућ је само у домену граматичких и фонетских варијанти једне исте компоненте фразеологизма и употребе синонимичних помоћних речи.

Појам фразеолошке варијанте за већину фразеолога ${ }^{1}$ је оправдан. Под варијантама фразеологизма подразумевају се „лексико-грамматические разновидности, тождественные по значению и степени семантической слитности” (Шанский 1985: 50). Према речима В. Мокијенка у фразеологији „,устойчи-

${ }^{1}$ Бертагаев, Зимин 1960; Коваленко 1969; Мокиенко 1989: 9-48; Сидоренко 1964; Шанкский 1985; Шкляров 1962, 1967. 
вость и неустойчивость тесно взаимодействуют, они предполагают друг друга и обеспечивают функционирование и динамику фразеологического фонда" (Мокиенко 1989: 48). Фразеолошке варијанте срећу се међу свим типовима фразеологизама (Белобородова 2009: 28). Већи број фразеологизама, код којих се разликује једна компонента, а значење тих различитих компонената тематски је повезано, чини фразеосхему (Драгићевић 2009: 39).

Предмет овог радаје анализа несинонимских лексичких варијанти у фразеологизмима који садрже компоненте чёрт у руском и враг српском језику. У науци о језику, према обиму устаљених израза који обухвата, фразеологија се дели на фразеологију у ужем и фразеологију у ширем смислу. Према ужем приступу, којим се руководимо у овом истраживању, фразеологизмима се сматрају фразеолошке сраслице, фразеолошка јединства и фразеолошки спојеви. ${ }^{2}$ Стога, под фразеологизмом подразумевамо релативно устаљене експресивне спојеве речи са целовитим значењем, које се не може извести из збира значења компонената а у језику се употребљавају у готовом виду (Мокиенко 1989: 5). Са структурног становишта фразеологизам у ужем смислу представља спој лексема које могу имати синтагматску структуру или „реченичну структуру, али незавршену, отворену” (Мршевић-Радовић 1987: 23).

Циљ овог рада је утврђивање сличности и разлика у броју, структури, тематској припадности несинонимских лексичких варијанти компонената чёрт у руском и враг српском језику, утврђивање њиховог односа према компонентама чёрт и враг, откривање мотивације њихове употребе на месту датих лексема. Компаративну и контрастивну анализу варијантних компонената на синхроном плану употпунићемо елементима дијахроне (етимолошке) анализе, концептуалне и лингвокултуролошке анализе.

Када говоримо о изворима истраживања, морамо истаћи да поједини аутори фразеолошких речника бележе варијантне компоненте фразеологизма исказане лексемама под једном речничком одредницом (Менац 1979-1980; Оташевић 2012; ФСРЯ; БФСРЯ), док их други аутори не наводе (РСАНУ; РСЈ; ФРХСЈ; МАС; ФСРЛЯ).. ${ }^{3}$

Корпус овог истраживања чини 56 фразеологизама (23 фразеологизма из руског језика (прилог 1), 33 фразеологизма из српског језика (прилог 2)) у којима се уз компоненте чёрт и враг дају лексичке варијанте или дате компоненте и саме представљају варијанту неке друге лексеме.

\footnotetext{
${ }^{2}$ Класификацију фразеологизама В. Виноградова (Виноградов 1977) према критеријуму семантичке спојености на фразеолошке сраслице, фразеолошка јединства и фразеолошке спојеве употпунио је Н. Шански фразеолошким изразима, дефинишући их као „устойчивые в своём составе и употреблении фразеологические обороты, которые не только являются семантически членимыми, но и состоят целиком из слов со свободным значением" (Шанский 1985: 62). Последња група укључена је у домен проучавања фразеологије у ширем смислу.

${ }^{3}$ Примере из речника РСАНУ, РСЈ и ФРХСЈ, у којима се лексичке варијанте не наводе у загради узимамо са резервом, будући да смо из њих ексцерпирали само изразе који садрже компоненте враг и Ђаво. Као допунуски извор фразеологизама користили смо монографију Наташе Вуловић Српска фразеологија и религија: лингвокултуролошка истраживања (Вуловић 2015) и и иад Ружице Бајић и Наташе Вуловић „Семантичко-фразеолошка анализа неких лексема са сакралним значењима у српском језику (анђео, ангел / демон, бес)” (Бајић, Вуловић 2009)
} 
Чёрт и враг. Именица чёрт (чорт ${ }^{4}$ ) у речнику МАС дефинише се: 1. по религиозным представлениям сверхъестественное сущзество, олицетворяющее собой злое начало, дьявол, бес. 2. прост(оречное) употребляется как бранное слово. 3. в знач. нареч. чёртом. прост(оречное), лихо, молодиевато; у БТСРЯ: 1. по религиозным представлениям: сверхъестественное существо, олицетворяющее собой злое начало, в образе человека, но с рогами, копьтами и хвостом; дьявол, бес. 2. нар(одное)-разг(оворное) употребляется как негативная характеристика кого-л. 3. разг(оворное)-сниж(енное) о том, кто обнаруживает умение, силу, сноровку, ловкость и m.n.; у ТСРЯ Шв: 1. в религиозных представлениях и народных поверьях: нечистый дух, олицетворяюший зло (изображаемый обычно человекоподобным существвом в шерсти, с рогами, копытами и хвостом). 2. на что, в чём или с неопр. о том, кто ловок, смел, удачлив в каком-н. деле (прост.). Према РСХС на српски језик преводи се лексемама ђаво и враг. Лексема враг у РСАНУ одређује се: 1. а. рлг(религијско). и празн(оверно) по народном веровању натприродно биће које живи обично у паклу, замишьено као оличење зла. б. у емоционалним обртима (клетвама, узречицама, у љутюи и сл.), често са избледелим значењем. 2. фиг(уративно). а. несташно, немирно или обесно створење. б. зло, опако, бесно створење. в. зло, невоља, незгода. г. (при помињању нечега рђавог или непријатног, у ьутњи, грдњи, негодовању и сл.) назив за било какво биће, предмет, појаву и сл. (често у питањима). 3. арх(аично) непријатељ, противник.

Лексема чёрт порекло води од:

„*[...] 'черта; очерченное место’ > ‘раскорчёванное место в пределах обозначенных границ’ > 'граница, как место обитания нечистой силы”, (ТСРЯ Шв).

Како се у БФСРЯ наводи, чёрт је демонски дух, који своје порекло води од општесловенских претхришћанских религиозно-митолошких и колективно-родовских представа, којима се хаос трансформише у човеку појмљив космос. Код Источних Словена чёрт представља појам који укључује сву нечисту силу (БФСРЯ: 721, а према СМЭС: 391, 392). Ово нечисто антропоморфно-зооморфно биће, има атрибуте човека и животиње (рогови, реп, копита, крзно), константно се меша у животе људи, терајући их да чине лоше, неоправдане, погрешне поступке. Исте атрибуте проналазимо код лексема враг, ђаво, сатана, сотона.

Како показује наш материјал, компонента чёрт у руским фразеологизмима може алтернирати с: 1) именицама - аллах, бог, бес, господь, грех, дьявол, ляд, пёс, прах, хрен, шиш, шут, поимениченим придевима - леший, нелёгкая, нечиcтый, 2) синтагмама (придев + именица): нечистая сила, нечистьй дух, чёртова мать, чёртова бабушка, черти собачьи. Као варијантне компоненте враг у корпусу српских фразеологизама појављују се: 1) именице: бес, бог, ђаво, нечастиви, 2) синтагме: придев + именица жиљьти враг, број + именица сто бесова, сто ђавола.

\footnotetext{
${ }^{4}$ Према правопису руског језика (дело, година, страна) до 1956. године именица се пише двојако чёрm / чорт. Реформом руског језика 1956. године донет је нови Правилник руске ортографије и пунктуације (дело, година) према којем се само облик чёрт сматра исправним.
} 
У раду синонимима именујемо само оне лексеме које проналазимо у речницима синонима руског и српског језика. ${ }^{5}$ Од наведених варијантних компонената у ССРЯ проналазимо: бес, дьявол, нечистый, нечистый дух, нечистая сила, а у РССЈ - ђаво, бес, нечастиви.

Варијанту бог срећемо у оба језика. Ова компонента, заједно са компонентама аллах и господь у руском језику, у антонимском је односу према лексемама чёрт и враг и налази се на позитивном поларитету бинарних опозиција Бог - ђаво, добро - лоше, чисто - нечисто, горе - доле, небо - земља, док су остале варијантне компоненте представници негативног поларитета: бес (бес), дьявол (Ђаво), нечистый (нечастиви), нечистый дух (нечисти дух), нечистая сила (нечиста сила)). Бог је једина лексичка варијанта компоненте враг у српском језику, коју, будући да је антоним, не проналазимо у РССЈ. Све остале варијантне компоненте овај речник региструје, због чега их нећемо детаљније анализирати у овом раду.

У народном веровању и Бог и враг поседују знање које није доступно обичном човеку, о чему сведоче фразеологизми: бог (господь, аллах, чёрт, бес, леший, иут, пёс, хрен) <его (тебя, её, вас, их)> знает (ведает); бог (господь, аллах, чёрт, бес, леший, пёс) знает; бог (чёрт) знает что; одному (единому) богу (господу, аллаху, чёрту) известно. Према Д. Мршевић-Радовић „у народној фразеологији је уобичајено да се далеки простор (даљина) најпре резервише за зла и опасна демонска бића" (Мршевић-Радовић 2014: 33). Тако се у искључиво просторном значењу употребљава фразеологизам богу (врагу) иза леђа (за леђима) (рус. у черта на кулички (на куличках)).

Варијантне лексеме које се не појављују у ССРЯ, а нису ни антоними јесу: грех 6 , леший, ляд, нелёгкая, пёс, прах, хрен, шиш, иут. Међу овим лексемама религијску конотацију имају грех и прах, религијско-митолошку - лексеме леший, ляд, нелёгкая, хрен, ииш, иут.

Када Срби желе да кажу да је нешто исто, користе фразеологизам није ђаво него враг. О томе да Ђаво и враг нису апсолутни синоними говори нам њихова етимологија. Сретен Петровић (2004) наводи да је претхришћански назив за Ђавола био израз чорт, с обзиром на то да је познат и у западнословенским и у источнословенским језицима. Овај израз је заједно са изразом враг старији назив за ђавола. Према ЕРХСЈ првобитно значење речи враг јесте непријатељ који убија, док му је хришћанство дало значење diabolus > Ђаво. Ова лексема се употребљава напоредо са прасловенском лексемом, те долази до њиховог укрштања. У описним речницима савременог српског језика „саме лексеме враг и Ђаво непрецизно [су] дефинисане. У њиховим примарним дефиницијама ова два значења [поглавар бесова (бијесова) и било који пали анђео, тј. демон, бес (бијес)] се не разлучују" (Бајић, Вуловић 2009: 277).

Чёрт и грех. Прва од варијантних лексема коју анализирамо јесте апстрак-

${ }^{5}$ Односи синонимије и антонимије у језику изузетно су комплексни. Неки од радова о овим односима су: Дешић 1983; Драгићевић 2007; Јакић 2016; Апресян 1969, 1974; Палевская 1964; Брагина 1986.

${ }^{6}$ У српском језику у РСАНУ значење 3. б. празн.(оверно) зао дух, Ђаво, тј. синонимно је са враг. 
тна именица са могућим конкретним реализацијама - грех (нарушавање религиозних правила и прописа, оно што лежи на савести, поступак за осуду, грешно, лоше (ТСРЯ Шв). Према ЭСРЯ највећа је вероватноћа да је словенско grěxъ повезано са лексемом греть, чије је првобитно значење печење (савести). Ову претпоставку оповргава ЕРХСЈ, истичући да је лексема грех ${ }^{7}$ старија од хришћанства, стога изворно није могла имати наведено значење. Изворна семантика греха (крив, одступање од правог) омогућила му је „да постане један од богословских термина у преводима на старословенски језик, у складу са хришћанским учењем да је грех одступање од правог пута ка циљу, чији су путоказ Божији закони, те је и суштина греха скретање с овога пута, промашај циља" (Грковић-Мејџор 2013: 371).

Према хришћанском предању первородный грех (срп. првородни (Адамов, источни, праотачки, прародитељски, први) грех), онај са којим се људи рађају, починили су Адам и Ева пробавши забрањени плод са дрвета познања добра и зла. Према религиозним представама хришћана постоје смртни грехови (рус. смертный грех), који се ничим не могу искупити и због којих се губи божја милост (РСЈ: 212, ФСРЯ: 120), а који носе назив семь смертных грехов (срп. седам смртних (самртних) грехова). Уколико неко учини поступак за осуду или свали грех на душу на руском ћемо употребити израз хватить греха на душу. Грех се може искупити (рус. замолить (замаливать) грех) и отпустити, односно опростити (рус. отпустить (отпускать) грехи). Човек може преузети грех на себе (рус. взять (брать, принять (принимать)) грех на душу (на себя)), сносити последице за туђу кривицу, односно расплатиться (расплачиваться) за чужие грехи (срп. испаштати (искајавати) туђе грехе), или пак, замерити некоме нешто, осудити некога за нешто, односно срп. уписати (приписивати, узимати и сл.) у грех. За трагикомичну ситуацију Руси ће рећи и смех и грех (срп. не знам да ли бих се смејао или плакао). Уколико неко добија према заслузи, Срби ће употребити израз према свеиу и тропар, а Руси - по грехам кому. Израз као у инат на руски језик преводи се изразом как на грех (как назло). Грех се може крити, те уколико желимо да искрено нешто кажемо, можемо употребити израз что (нечего) греха таить (срп. ито да се таји, руку на сриее, треба признати). Он се може реализовати и као простор: човека могу други увести у грех: ввести (вводить) в грех (соблазн) (срп. (бити) наведен на грех (увести у искушење)), човек може и сам упасти у њега: впасть (впадать) в грех (спр. упасти у грех) и заглибити се, увалити се, огрезнути у грехе: погрязнуть (погрязать) в грехах (срп. огрезнути у грех). Близином греха може се описати неповољна животна ситуација, невоља, незгода: долго ли до греха (срп. враг (Ђаво) не спава, није далеко до невоље, лако се може догодити, не треба (не фали) много). Некоме можемо препоручити да нешто остави (да се мане нечега) изразом от греха (nодальще) (срп. мани се тога). О физичкој реализацији греха у пољу човековог изгледа говори нам поредбени фразеологизам дурен (страшен) как смертный грех (срп. ружан као страшило, као ђаво, као грех ${ }^{8}$ ). Грех може имати времен-

${ }^{7}$ О концепту греха у српском и руском језику видети: Вуловић 2015: 266-273: Керкез 2007; Сайгин 2013, 2014.

${ }^{8} \mathrm{O}$ последњем примеру ружан као грех Н. Вуловић пише да се у фразеолошком речнику хрватског језика овај пример наводи, док се у нашем језику појављује у новијим књижевним 
ску димензију, те потицати из младости или прошлости (рус. грехи молодости, грехи прошлого). Он може бити материјализован као ствар или предмет који се може делити, па за поједине радње и послове на руском кажемо с грехом пополам 9 (срп. на једвите јаде, с тешком муком). У изразу грех попутал активност субјекта радње говори нам о аниматности именице грех. У РСАНУ међу значењима лексеме грех проналазимо 3. б. празн(оверно) зао дух, ђаво. У БАС и МАС ова значења не проналазимо, стога сматрамо да у руске фразеологизме улази захваљујући механизмима метонимије.

Чёрт и леший. Лексема леший припада кругу словенске митолошке лексике и ,по свој прилици први пут се помиње у писаним изворима тек у XVI веку, под називом лессны богъ” (Раденковић 2013: 13). На српски језик ову лексему преводимо синтагмом шумски дух, будући да за реч леший, лесник Срби и Хрвати нису знали, као ни Бугари, нити Македонци (Раденковић 2011: 35).

Овај демон словенске митологије господар је шуме и звери. Сам његов физички опис представљен је као хаотичан, као супротан уређености, у појединим сегментима близак опису врага. То што се веровало да нема сенке и да му је крв плава, говори у прилог оностраној природи овог моћног митолошког бића, чији су послушници вукови, који су такође један од атрибута нечистог. Све што је проклето - његов је плен. Према речима Љ. Раденковића, леший је један од демона, који својим појављивањем предсказују несрећу. Друга његова функција јесте заштита. Према северним руским веровањима он не само што прати војнике у рат, већ и прима метке за њих, може да украде дете и да заштити дивљу звер. Из овога закључујемо да је реч о демонском бићу чија природа „указује на заједничке корене божанског и демонског у старој словенској митологији, тј. на везу митолошких бића са обоготвореним прецима, с једне стране, као и са застрањеним покојницима, с друге” (Раденковић 2013: 13).

Двојаки однос према овом бићу потврђује руска фразеологија. Као враг, шумски дух утиче на човека да чини лоша дела, да говори оно што не треба: леший дёрнул (дёрнет), леший дёрнул меня за язык. Он носи, узима оне чијим присуством или којима смо незадовољни: леший несёт (носит, принёс итд.), леший с ним, леший его возьми (дери, побери, подери). Њега помињемо када се чудимо, дивимо, када смо усхићени или изражавамо непријатност: на кой (какой) леший, за каким (коим) лешим, какого лешего; када изражавамо изостанак некога или нечега: ни лешего; или, пак, грдњу, прекор: к лешему. У три примера из нашег корпуса могућа је замена компоненте леший лексемом бог. У овим примерима или се претпоставља свезнање Бога и нечисте силе, наспрам незнања човековог - леший его знает (ведает), леший знает <кто, когда итд.>, или се изражавају грдње и прекори - ну его клешему. Лексема леший појављује се у као варијантна компонента свог хиперонима чёрт у фразеологизмима.

стилски маркираним текстовима. Аутор претпоставља да је „ширење ове фразеолошке јединице последица културних контаката, највише превођења и уопште утицаја западне културе” (Вуловић 2015: 273).

${ }^{9}$ Наведени пример има и друго значење које се сматра застарелим: $c$ грехом пополам - 1 . с большим трудом, еле-еле, кое-как. ср. с горем пополам. 2. устар. сомнительным путем, неблаговидным способом, нечестно, с обманом (ФСРЯ: 344$)$. 
Чёрт $и$ ляд. Именицу ляд речници наводе само у оквиру израза (МАС, ТСРЯ Уш, ТСРЯ Шв), или као народни разговорни синоним лексеме леший (БТСРЯ), а њој сродне именице ляда и лядина дефинишу као: 1) ниско влажно место обрасло шумом или жбуњем, 2) раскрчено место од шуме или 3) јаругу, односно ледину (МАС, БТСРЯ, ТСРЯ Уш). Према ЭСРЯ порекло лексеме ляд објашњава се лексемом ледачий у значењу непутёвый (разг. лакомислен, нехатан, ветропираст. РСХС), негодный (1. неприкладан, неподесан; неупотребљив. 2. разг. лош, рђав. РСХС) и пољском лексемом ladaczy (рус. чёрт). Лексемом ляд у дијалекатској лексици топонимије Костромске области бавила се Ј. В. Цветкова (2011). Ауторка на основу броја деривата ове именице - именица: ляд; ляда (леда), ляды (леды), лядина (ледина), лядинка (лединка), лядинник, придева: лядащчий (ледащчий, лядящฺии, лядащенький, ляже(ё) нное, глагола: лядеть (ледеть) - болеть, слабеть, чахнуть, закључује да је дата лексема веома продуктивна на овом подручју. Најпродуктивнија је у називима ливада за кошење и испашу, називима шума, шумарака и места у шуми, зараслих поља, остављених због лоше, неплодне земље. Лексема ляд у костромским дијалектима има и значења: зао дух, ђаво у народним веровањима, болест, немоћ, слабост, невоља, а користи се и као назив за бичевалце (припаднике секте самобичевања).

У нашем корпусу потврђена су два фразеологизма са овом компонентом и у оба се ова компонента може заменити лексемом чёрт. Један од њих користи се када се изражава чуђење, дивљење, усхићење, непријатност: на кой (какой) ляд; а други приликом грдње, прекора: иди (пошёл, ну тебя итд.) к ляду. Појаву именице ляд као варијантну компоненту именице чёрт можемо тумачити на два начина: 1) именица означава злог духа и хипоним је именице чёрт, 2) именица означава хабитат чёрта. У оба наведена случаја именица улази у наведене фразеологизме путем метонимије.

Чёрт и нелёгкая. Придев нелёгкий бележе сви анализирани описни речници руског језика (БТСРЯ, МАС, ТСРЯ Шв, ТСРЯ УШ). Лексему нелёгкая као посебну одредницу бележе ТСРЯ Уш и ТСРЯ Шв само у оквиру израза, док је МАС и БТСРЯ не бележе не само као одредницу, већ ни као једно од значења лексеме нелёгкий.

Овај поименичени придев настао је елидирањем именице сила и представља еуфемистичан назив за сву нечисту силу (вукодлаке, вампире, шумске и кућне духове, и сл.), чиме се објашњава способност ове компоненте да у појединим фразеологизмима замењује именицу чёрт. Нечистоћа води порекло из архетипске опозиције чисто - нечисто, прљаво (БФСРЯ: 721). У фразеологији се дати поименичени придев углавном користи у једнини. Нечиста сила наводи људе да чине и говоре оно што не треба: нелёгкая меня дёрнула, нелёгкая дёрнула меня за язык, утиче на њихово понашање нелёгкая попутала кого, њу помињемо када изражавамо незадовољство: нелёгкая несёт кого, нелёгкая несёт кого куда, нелёгкая носит кого, нелёгкая носит кого где. Једини пример у фразеолошким речницима у којем се дати поименичени придев користи у множини јесте: $n y$ скаться (пуститься) во все нелёгкие (тяжкие, во вся тяжкая) (срп. одати се (одавати се) пијанству, разврату; не бирати средтва <за постизање изиља>). На српски језик преводи се лексемама враг и ђаво. 
Чёрт и пёс. Општесловенско порекло речи пас потврђује његова распростањеност у савременим словенским језицима, као и етимологија (др.-рус., ст.слав. $n ь c ъ$, укр., блр., болг. пес, с-хорв. nac, словен. pes, чеш., слвц. pes, польск. pies (ЭСРЯ)).

Лексему пёс у руском језику временом је потиснула лексема собака. Како се наводи у етимолошким речницима, порекло именице пёс није јасно. Иако најстарија припитомљена животиња, која је хиљадама година саставни део човековог окружења, пас је, као предмет многовековног посматрања, поред позитивних, дао повода и за негативне оцене од стране људи. Ове оцене нашле су одраз како у лексици, тако и у фразеологији.

У руској фразеологији пас се као варијантна компонента појављује у изразима чуђења, изненађења, непријатности: на кой пёс, незадовољства: пёс меня возьми; приликом изражавања незадовољства нечијим доласком, одласком, понашањем: пёс с ним; у грдњама, претњама, псовкама: ко <всем> псам (чертям собачьим). Срби изражавају узалудност, безвредност нечега изразом мачку под реп (бацичти), док Руси говоре: псу под хвост (срп. узалуд, утутањ, не вреди ни пишљьва боба). О свезнајућој природи пса говори нам његова заменљивост лексемом бог у изразима: пёс <его> знает, пёс знает.

Према речима В. Чајкановића добро је познато да је „одвратност према псу дубоко укорењен осећај код нашег народа" (Чајкановић 1994: 247, 248). Аутор истиче да су светост и поганост ове животиње доказ њене демонске природе (Чајкановић 1994: 249). Ово веровање води порекло из паганске, словенске и старе српске митологије. Облик пса могу попримити и друга створења из словенске митологије: домовој у Русији, вампир у Чешкој и Пољској, душе покојника у Србији (Чајкановић 1994: 256). О култу пса као хтонске нечисте животиње говоре и остаци „псећих” празника (Чајкановић 1994: 243-260).

Чёрm u прах. Према БФСРЯ представа о праху као прашини, укупности најситнијих честица, потиче из давнина. Именица прах води порекло из црквенословенског и старословенског језика. У савременом руском језику сматра се застарелом и стилистички обојеном речју, користи се у пренесеном значењу и поетском изражавању, а њена општа значења пренета су на лексему порох.

Лексема прах у руској фразеологији је заступљена: у уобичајеној формули при опросту с мртвима мир праху его (срп. мир праху његовом), здесь покоится прах кого, чей (срп. овде почива ко); приликом изражавања чуђења, изненађења, непријатности: на кой (какой) прах, незадовољства: прах его возьми (дери, побери, подери), прах с ним, прах тебя знает (разберёт) (срп. ко би те знао, ко ће те знати); грдњи, претњи, псовки: гори прахом! (срп. нека све иде бестрага!), чтобы <и> праху не было (срп. губи ми се с очију, да те више не видим овде, нестати без трага, нећу да знам за тебе); у значењу - до краја, до крајњих граница: разориться (промотаться итд.) в пух и $<_{\boldsymbol{B}}>$ прах (срп. пропасти до краја, скрхати се, пасти на просјачки штап), разбить в пух и $<_{B}>$ прах (срп. разбити у парампарчад, потући до ногу), пойти/идти (рассыпаться/рассыпаться) прахом (срп. пропасти/пропадати, претворити се/претварати се у прах и пепео; отићи утутањ (у ветар)). У фразеосемантичком пољу међуљудских односа приликом изражавања критике користи се фразеологизам: 
разнести в пух и <в> прах (срп. опрати главу коме, искритиковати, уништити кога). Прекидање везе с неким или нечим у руском језику изражава се фразеологизмом отрясти (отряхнуть) от <своих> ног прах (срп. прекинути сваку везу с ким, с чим, дефинитивно напустити кога, ита). Овај израз (Шулежкова 2011: 279) потиче од древног обичаја да се приликом одрицања познанства, старог пријатељства, родбинских веза, напуштања одређеног непријатног места, на прагу или на граници удара ногом о земљу, како би се отресле и најситније њене честице. Ауторка сматра да је овај чин прешао у религиозне радње првих хришћана, а отуда и у Свето Писмо.

Прах је реч која се спомиње у Светом Писму, како у Старом Завету: „Са знојем лица својега јешћеш хљеб, докле се не вратиш у земљу од које си узет; јер си прах, и у прах ћеш се вратити. ” (І Мс. 3: 19) 3: 19), тако и у Новом Завету: „Ако вас ко не прими нити послуша ријечи ваше, излазећи из куће, или из града онога, отресите прах са ногу својих " (Мт. 10: 14). Прах се налази на негативном поларитету више опозиција: небо - земља, горе - доле, Бог - човек, вечно - пролазно, чисто - нечисто, чиме се објашњава повезаност лексеме са лексемом чёрт.

Чёрт и хрен. Лексема хрен према МАС јесте 1. травянистое растение сем. крестоиветных, с утолщенным корнем, содержащим едкое эфирное масло, идущиим в пищу в качестве приправы. 2. горький корень этого растения, а также пряная приправа к пище из этого корня. У РС наводи се једно значење, којим су обухваћена оба значења у руском језику, односно, хрен је врста поврћа, вишегодишьа зељаста биљка из ф. крсташица, чији се љути ароматични корен употребљава као зачин. Због свог облика и укуса у хришћанству је постао симбол Христових мука и страдања (Шадура 2010: 341).

У фразеосемантичком пољу људских физичких особина старост се може изразити фразеологизмом старый хрен (у МАС са квалификатором прост(оречное) бран(ное); у ФСРЛЯ грубо-прост(оречное); у ФСРЯ фразеологизам се не наводи) (срп. старкеља, старо гунђало), а незгодна, несрећна животна ситуација - пословицом хрен редьки не слаще (срп. не зна се шта је горе, зло је једно и друго, није ђаво него враг, све је исти враг (Ђаво)), којом се подвлачи оштар, љут, горак, опор укус ове биљке као подсећање на муке Исусове (Шадура 2010: 341). Овај еуфемизам за врага користи се и приликом исказивања изненађења, чуђења, и незадовољства хрен его знает (ведает), на кой (какой) хрен, какого хрена, хрен в голову (пятку) (срп. види врага!, Ђаволе <један>!, враг те однио!), незадовољства: хрен с ним, док се за изостанак нечега користи израз ни хрена.

Чёрт и шиш. Лексема ииш дефинисана је као 1. оштар врх нечега, 2. шипак, 3. јако мала количина нечега (MAC). У ЭСРЯ као једно од могућих порекла и значења речи наводи се „диал. также «черт», смол. (Добровольский), донск. (Миртов), [...] От шиш «черт» произведены шиши́га, шишига́н, шишко́”. На српски језик преводи се као шипак, фига.

Користи се у изразима када се жели исказати: ништа (не добити или не дати): шиш с маслом (срп. фига, иипак, ништа; свирај ти, брајко), показать шиш кому (срп. показати шипак (фигу) коме), получить ииш (фигу) <с маслом> (срп. добити иипак (фигу, брус), не добити ништа, остати празних шака), 
незадовољство поводом изостанка некога/нечега: ни шиша; средство, новац: на какие шиши <жить, покупать, приобретать итд.> (срп. од каквих средстава (каквим средствима, којим парама) <живети, куповати, стищати >).

Везу између шиша и врага проналазимо у дијалектима руског језика. У Кировској области у водене духове убраја се шишига, која личи на одраслу дугокосу жену, без одеће, коју често чешља, излазећи на земљу из воде. Корен се везује и за кикимору (кикимара, шишимора, шишимара, мара), духа у облику жене, који се појављује у кући, конаку, опустелим грађевинама, а изведеница шишимора везује се за глагол иишить, иишать - комешати се, врзмати се, мрдати се, радити кришом. Овим термином у различитим крајевима обележавају се различити митолошки женски ликови међу којима су: жена кућног духа, жена лесног духа, русалка, чак и фигура која се палила за празник Масленицу (Власова 2008: 78-82). Бавећи се позајмицама из руског језика у језику народа Коми у Пермској области, И. Подјуков (Подюков 2012) бележи називе за чичак, стричак (рус. репейник, чертополох) - шишибар. Дуго се сматрало да је ова реч угро-финског порекла, као и сам народ, међутим В. Меркулова је показала да је назив настао највероватније аналогијом са чертополох (шиш - дијал. чёрт, бор од борити, борити се према полох, полохать - плашити) (Подюков 2012.

Чёрт и шут. Српски превод именице шут у РСХС гласи 1) дворска луда, 2) лакрдијаш, пајац. Везу између шута и черта можемо потражити у етимологији. Према речима М. Турилове (2008) важан елемент семантике шута јесте празноћа, пустош (шутило - ован без рогова). Уз то, проклете особе мушког пола називају се шутови на Уралу, а русалка - шутовка. Она може бити и жена или кћи шута, „а шутом называют эвфемистически чёрта” (Зеленин 1995: 146). Негативној слици дворске луде доприноси и маска, односно одсуство лица, чиме се представља онострано, опасно, демонско. Изразе са овом лексемом користимо приликом исказивања незадовољства поводом нечијег доласка, или одласка: шут возьми (дери, побери, подери), ну его к иуту, шут с ним, изостанка или недостатка нечега: ни шута, чуђења, изненађења: на кой (какой) шут, какого шута, прекора и грдњи: к шуту. Човек од себе може правити дворску луду: разыграть (разыгрывать) шута горохового, строить из себя шута (срп. правити се будала), или се облачити као она: нарядиться (рядиться) шутом (срп. обући се (облачити се) као клаун, направити (правити) од себе будалу, комедијашити).

Материјал нашег истраживања показао је да постоји више српских фразеологизама с компонентом враг у којима се она може заменити другом лексемом, него руских фразеологизама у којима се компонента чёрт може заменити другом лексемом (33 фразеологизма у српском, наспрам 23 у руском језику). Разноликост и број лексичких варијанти компоненте чёрт знатно је већи од броја варијанти компоненте враг (20 у руском, наспрам 7 у српском језику). У српском језику све варијанте осим лексеме бог проналазимо у РССЈ. У руском језику, осим варијантне компоненте бог (аллах, господь), која је антоним лексеми чёрm, проналазимо и синонимске и несинонимске лексеме. Несинонимске лексеме које имају религијску (грех и прах) или митолошку конотацију (леший, ляд, нелёгкая, хрен, ииш, шут), те у анализи нису уочене измене у унутрашњој форми фразеологизама. Међу варијантама компоненте чёрт заступљени 
су еуфемизми (нелёгкая, хрен), хипоними (леший, пёс, иши, шут) и метоними (грех, прах, ляд). Анализирани фразеологизми најчешће се употребљавају за изражавање чуђења, изненађења, непријатности, незадовољства, грдњи, претњи, псовки. Све варијанте компоненте чёрт у анализираном корпусу на српски језик преводе се фразеологизмима са лексемама враг и ђаво.

Одговор на питање откуда толики број лексема које могу заменити речи чёрт и враг у фразеологији можемо потражити у народном веровању да се именовањем зла оно привлачи, због чега се ,замењује погрдним називима или еуфемизмима: некрштеник, налетник, нечастиви, нечастивник, нежид, брадаило, куси, репоња, рогоња, водац, матори, проклетник, анатемник, анђама" (Кулишић и др. 1970: 127). Када се упореде народна веровања о божанској и нечистој сили, закључује се да „первые восходят к христианству, а вторые - во многом к славянскому язычеству” (Волков и др. 1996: 147).

Фразеологизмима се, као фрагментом језичке слике света, фиксирају и преносе с поколења на поколење информације о стереотипима, еталонима и архетиповима заступљеним у одређеној култури. У својој семантици они одражавају дуг процес развоја културе народа (Маслова 2001: 82). На основу анализираних фразеологизама можемо закључити да, у оном делу руске и српске језичке слике света који се односи на народне и религијске представе о чёрту и врагу, постоји велика подударност, али и специфичност сваке од њих. Наше истраживаање могло би представљати део свеобухватнијег истраживања фразеологизама у које би били укључени сви синоними датих компонената у оба језика, чиме би се омогућило доношење дубљих закључака о њиховом месту у фразеолошком фрагменту језичке слике света двају народа.

\section{Цитирана литература}

Апресян, Юрий Д. «Синонимия и синонимы». Вопросы языкознания 4, 1969: 75-91. [Apresân, Ûrij D. «Sinonimiâ i sinonimy». Voprosy âzykoznaniâ 4, 1969: 75-91]

Апресян, Юрий Д. Лексическая синонимия: синонимические средства языка. Москва: Наука, 1974.

[Apresân, Ûrij D. Leksičeskaâ sinonimiâ: sinonimičeskie sredstva âzyka. Moskva: Nauka, 1974]

Бабкин, А. М. Русская фразеология, ее развитие и источники. Ленинград: Наука, 1970.

[Babkin, A. M. Russkaia frazeologiiā, ee razvitie i istochniki. Leningrad: Nauka, 1970]

Бајић, Ружица. Наташа Вуловић. „Семантичко-фразеолошка анализа неких лексема са сакралним значењима у српском језику (анђео, ангел / демон, бес)”. Црквене студије VI, 2009: 271-279.

[Bajić, Ružica, Nataša Vulović. „Semantičko-frazeološka analiza nekih leksema sa sakralnim značenjima u srpskom jeziku (anđeo, angel / demon, bes)". Crkvene studije VI, 2009: 271-279.]

Белобородова, Анна В. «Вариативность фразеологических единиц, репрезентирующих концепт «безразличие» в русском и английском языках». Филологические науки. Вопросы теории и практики1/3, 2009: 27-29.

[Beloborodova, Anna V. "Variativnost' frazeologicheskikh edinits, reprezenti- 
ruiushchikh kontsept «bezrazlichie» v russkom i angliı̌skom iazykakh». Filologicheskie nauki. Voprosy teorii i praktiki 1/3, 2009, 27-29]

Бертагаев, Трофим А., Валентин И. Зимин, «О синонимии фразеологических словосочетаний в современном русском языке». Русский язык в школе 3, 1960: 4-10.

[Bertagaev, Trofim A., Valentin I. Zimin, «O sinonimii frazeologicheskikh slovosochetaniĭ v sovremennom russkom iāzyke». Russkiı̌ iāzyk v shkole 3, 1960: 4-10]

Брагина, Алла А. Синонимы в литературном языке. Москва: Наука, 1986.

[Bragina, Alla A. Sinonimy v literaturnom âzyke. Moskva: Nauka, 1986]

Виноградов, Виктор В. Избранные труды. Лексикология и лексикография. Москва: Наука, 1977.

[Vinogradov, Viktor V. Izbrannye trudy. Leksikologiiā i leksikografiiā. Moskva: Nauka, 1977]

Власова, Марина Н. Энциклопедия русских суеверий. СПб: Азбука-классика, 2008.

[Vlasova, Marina N. Ėnt șiklopediiâ russkikh sueveriǐ. SPb: Azbuka-klassika, 2008]

Волков, Владимир К. и др. Очерки истори и культуры славян. Москва: Индрик, 1996.

[Volkov, Vladimir K. i dr. Ocherki istori i kul'tury slaviān. Moskva: Indrik, 1996]

Вуловић, Наташа. Српска фразеологија и религија: лингвокултуролошка истраживања. Београд: Институт за српски језик САНУ, 2015.

[Vulović, Nataša. Srpska frazeologija i religija : lingvokulturološka istraživanja. Beograd: Institut za srpski jezik SANU, 2015]

Грковић-Мејџор, Јасмина. „Прилог историји лексичко-семантичке групе -greh-”. [У:] Ј. Грковић-Мејџор и К. Кончаревић (уред.) Теолингвистичка проучавања словенских језика. Београд: Институт за српски језик САНУ, 2013, 369-388.

[Grković-Mejdžor, Jasmina. „Prilog istoriji leksičko-semantičke grupe -greh-”. [U:] J. Grković-Mejdžor i K. Končarević (ured.) Teolingvistička proučavanja slovenskih jezika. Beograd: Institut za srpski jezik SANU, 2013, 369-388]

Дешић, Милорад. „О лексичким синонимима”. Наш језик 26/1, 1983: 34-41.

[Dešić, Milorad. „O leksičkim sinonimima”. Naš jezik 26/1, 1983: 34-41]

Драгићевић, Рајна. Лексикологија српског језика. Београд: Завод за уџбенике и наставна средства, 2007.

[Dragićević, Rajna. Leksikologija srpskog jezika. Beograd: Zavod za udžbenike i nastavna sredstva, 2007]

Драгићевић, Рајна. „О проблемима идентификације фразеологизама”. Sűdslavistik Zeitschrift für südslavische Sprachen, Literaturen und Kulturen 1, 2009: 35-44.

[Dragićević, Rajna. „O problemima identifikacije frazeologizama”. Südslavistik Zeitschrift für südslavische Sprachen, Literaturen und Kulturen 1, 2009: 35-44.]

Зеленин, Дмитрий К. Избранные труды: Очерки русской мифологии: умершие неестественной смертью и русалки. Москва: Индрик, 1995.

[Zelenin, Dmitriı̌ K. Izbrannye trudy: Ocherki russkoı̆ mifologii: umershie neestestvennoĭ smert'iư i rusalki. Moskva: Indrik, 1995]

Јакић, Милена. Придевска антонимија у речнику, контексту и когнитивном систему. Докторска дисертација. Београд: Филолошки факултет, 2016.

[Jakić, Milena. Pridevska antonimija u rečniku, kontekstu i kognitivnom sistemu. Doktorska disertacija. Beograd: Filološki fakultet, 2016]

Керкез, Драгана. „Концепт 'грех’ као део језичке слике света код Срба и Руса”. [У:] Р. Симић (ур.) Српски језик и друштвена кретања, књ. 1. Крагујевац: ФИЛУМ, 2007, 309-316. 
[Kerkez, Dragana. „Koncept 'greh’ kao deo jezičke slike sveta kod Srba i Rusa”. [U:] R. Simić (ur.) Srpski jezik i društvena kretanja, knj. 1. Kragujevac: FILUM, 2007, 309-316]

Коваленко, Татьяна И. Вопросы синонимии глагольных фразеологизмов в современном русском языке. Автореф. канд. дисс. Ленинград, 1969.

[Kovalenko, Tat'iâna I. Voprosy sinonimii glagol'nykh frazeologizmov v sovremennom russkom iâzyke. Avtoref. kand. diss. Leningrad, 1969]

Кулишић, Шпиро, Петар Ж. Петровић, Никола Пантелић. Српски митолошки речник. Београд: Нолит, 1970.

[Kulišić, Špiro, Petar Ž. Petrović, Nikola Pantelić. Srpski mitološki rečnik. Beograd: Nolit, 1970]

Маслова, Валентина А. Лингвокультурология: учебое пособие для студентов высших учебных заведений. Москва: Академия, 2001.

[Maslova, Valentina A. Lingvokul'turologiia: ucheboe posobie dliā studentov vysshikh uchebnykh zavedeniı̌. Moskva: Akademiia, 2001]

Мокиенко, Валерий М. Славянская фразеология. Москва: Высшая школа, 1989.

[Mokienko, Valeriǐ M. Slaviānskaiā frazeologiiā. Moskva: Vysshaiā shkola, 1989]

Мршевић-Радовић, Драгана. Фразеолошке глаголско-именичке синтагме у савременом српскохрватском језику. Београд: Филолошки факултет, 1987.

[Mršević-Radović, Dragana. Frazeološke glagolsko-imeničke sintagme u savremenom srpskohrvatskom jeziku. Beograd: Filološki fakultet, 1987]

Мршевић-Радовић, Драгана. Фразеологија и нацианална култура. Београд: Друштво за српски језик и књижевности Србије, 2014.

[Mršević-Radović, Dragana. Frazeologija i nacionalna kultura. Beograd: Društvo za srpski jezik i književnosti Srbije, 2014]

Мутавџић, Предраг, Anastassios Kampouris. „Ко с ђаволом тикве сади... (прилог упоредном проучавању балканске фразеологије)”. Славистика XX, 2016: 44-72.

[Mutavdžić, Predrag, Anastassios Kampouris. „Ko s đavolom tikve sadi... (prilog uporednom proučavanju balkanske frazeologije)". Slavistika XX, 2016: 44-72.]

Палевская, Мария Ф. Синонимы в русском языке. Москва: Просвещение, 1964.

[Palevskaâ, Mariâ F. Sinonimy v russkom âzyke. Moskva: Prosveŝenie, 1964]

Петровић, Сретен. Српска митологија: у веровању, обичајима и ритуалу. Београд: Народна књига - Алфа - Невен, 2004.

[Petrović, Sreten. Srpska mitologija : u verovanju, običajima i ritualu. Beograd: Narodna knjiga - Alfa - Neven, 2004]

Подюков, Иван А. «Русская диалектная лексика в речи лупьинских Коми-Пермяков». Вестник Пермского университета: Российская и зарубежная филология. Вып. 3 (19), 2012: 14-21.

[Podiūkov, Ivan A. «Russkaiā dialektnaiā leksika v rechi lup'inskikh KomiPermiakkov». Vestnik Permskogo universiteta: Rossiǐskaiā i zarubezhnaiā filologiiā. Vyp. 3 (19), 2012: 14-21.]

Раденковић, Љубинко. «Известен ли южным славянам леший». Живая старина: Журнал о русском фольклоре и традиционной культуре 4, 2011: 34-37.

[Radenković, Ljubinko. «Izvesten li юžnыm slavяnam lešiй». Živaя starina: Žurnal o russkom folıklore i tradicionnoй kulıture 4, 2011: 34-37.]

Раденковић, Љубинко. „Словенска народна демонологија на синхроном и дијахроном плану”. Зборник Матице српске за славистику 83, 2013: 9-25.

[Radenković, Ljubinko. „Slovenska narodna demonologija na sinhronom i dijahronom 
planu”. Zbornik Matice srpske za slavistiku 83, 2013: 9-25.]

Сайгин, Вадим В. «Языковая экспликация концепта «грех» в современном русском языке». Вестник ВГУ. Серия: Лингвистика и межкультурная коммуникация 2, 2013: 113-115.

[Sajgin, Vadim V. «Âzykovaâ èksplikaciâ koncepta «greh» v sovremennom russkom âzyke». Vestnik VGU. Seriâ: Lingvistika i mežkul'turnaâ kommunikaciâ 2, 2013: 113-115]

Сайгин, Вадим В. «Концептуальное поле «грех» в концептосфере современного русского языка в аспекте словообразовательной деривации». Мир науки, культуры, образования 6/49, 2014: 331-333.

[Sajgin, Vadim V. «Konceptual'noe pole «greh» v konceptosfere sovremennogo russkogo âzyka v aspekte slovoobrazovatel'noj derivacii». Mir nauki, kul'tury, obrazovaniâ 6/49, 2014: 331-333]

Свето писмо Старога и Новога Завјета $<$ https://svetosavlje.org/bogosluzbeni/svetopismo/> 10.07.2021.

[Sveto pismo Staroga i Novoga Zavjeta $<$ https://svetosavlje.org/bogosluzbeni/svetopismo/> 10.07.2021]

Сидоренко, Михаил И. Принципы составления словаря фразеологических синонимов современного русского литературного языка. Автореф. канд. дисс. Ленинград, 1964.

[Sidorenko, Mikhail I. Printsippy sostavleniiā slovariā frazeologicheskikh sinonimov sovremennogo russkogo literaturnogo iāzyka. Avtoref. kand. diss. Leningrad, 1964]

СМЭС: Славянская мифология. Энциклопедический словарь (ред. В. Я. Петрухин, Т. А. Агапкина, Л. Н. Виноградова, С. М. Толстая). Москва: Эллис Лак, 1995.

[SMĖS: Slaviānskaiā mifologiiâ. Ėnțikiklopedicheskiı̌ slovar' (red. V. Iâ. Petrukhin, T. A. Agapkina, L. N. Vinogradova, S. M. Tolstaia). Moskva: Ëllis Lak, 1995]Турилова, Мария В. «О шуте и не только». Русская речь 2, 2008: 118-124.

[Turilova, Mariiâ V. «O shute i ne tol'ko». Russkaiā rech' 2, 2008: 118-124]

Федоров, А. И. Развитие русской фразеологии в конце XVIII - начале XIX в. Новосибирск: Издательство «Наука» - Сибирское отделение, 1973.

[Fedorov, A. I. Razvitie russkoĭ frazeologii v kontşe XVIII - nachale XIX v. Novosibirsk: Izdatel'stvo «Nauka» - Sibirskoe otdelenie, 1973]

Чајкановић, Веселин. Студије из српске религије и фолклора: 1925-1942. Београд: Српска књижевна задруга, 1994.

[Čajkanović, Veselin. Studije iz srpske religije i folklora: 1925-1942. Beograd: Srpska književna zadruga, 1994.]

Цветкова, Елена В. «Диалектная лексика в Костромской топонимии (ляд, ляда, лядина и т.д.)». Вестник КГУ им. Н. А. Некрасова 1, 2011: 105-109.

[Tş̌vetkova, Elena V. «Dialektnaiā leksika v Kostromskoĭ toponimii (liād, liāda, liādina i t.d.)». Vestnik KGU im. N. A. Nekrasova 1, 2011: 105-109]

Шадура, Иоанна Р. «Хрен в польском языке и культуре». Acta Linguistica Petropolitana. Труды Института лингвистических исследований, Т. 6, 1, 2010: 341-361.

[Shadura, Ioanna R. «Khren v pol'skom iāzyke i kul'ture». Acta Linguistica Petropolitana. Trudy Instituta lingvisticheskikh issledovaniǔ, T. 6, 1, 2010: 341-361.]

Шанский, Николай М. Фразеология современного русского языка: учеб. пособие для вузов по спец. «Русский язык и литература». Москва: Высшая школа, 1985.

[Shanskiĭ, Nikolaĭ M. Frazeologiiâ sovremennogo russkogo iâzyka: ucheb. posobie dliâ vuzov po spets. «Russkiî iâzyk i literatura». Moskva: Vysshaiā shkola, 1985] 
Шкляров, Владимир Т. «О фразеологических синонимах в русском языке». Труды кафедры русского языка. Т. ІІ, Иркутск, Т. 2, 1962, 112-132.

[Shkliârov, Vladimir T. «O frazeologicheskikh sinonimakh v russkom iâzyke». Trudy kafedry russkogo iāzyka. T. II, Irkutsk, T. 2, 1962, 112-132]

Шкляров, Владимир Т. «О словаре фразеологических синонимов». [В:] Р. Н. Попов (ред.) Проблемы фразеологии и задачи ее изучения в высшей и средней школе. Вологда: Сев.-Зап. кн. изд-во, 1967, 22-233.

[Shkliârov, Vladimir T. «O slovare frazeologicheskikh sinonimov». [V:] R. N. Popov (red.) Problemy frazeologii i zadachi ee izucheniiâ v vyssheĭ i sredneî shkole. Vologda: Sev.-Zap. kn. izd-vo, 1967, 22-233]

\section{Извори}

Једнојезични речници руског језика:

БТСРЯ: Большой толковый словарь русского языка (ред. С. А. Кузнецов). СанктПетербург: Норинт, 2000.

[BTSRÂ: Bol'šoj tolkovyj slovar' russkogo âzyka (red. S. A. Kuznecov). SanktPeterburg: Norint, 2000]

БФСРЯ: Большой фразеологический словарь русского языка. Значение. Употребление. Культурологический комментарий (ред. В. Н. Телия). Москва: АСТ - ПРЕСС ШКОЛА, 2018.

[BFSRÂ: Bol'šoj frazeologičeskij slovar' russkogo âzyka. Značenie. Upotreblenie. Kul'turologičeskij kommentarij (red. V. N. Teliâ). Moskva: AST - PRESS ŠKOLA, 2018]

MAC: Словарь русского языка в четырёх томах: издание третье, стереотипное (ред. А.П. Евгеньева). Москва: Русский язык, 1985-1988.

[MAS: Slovar' russkogo âzyka v četyrëh tomah: izdanie tret'e, stereotipnoe. (red. A.P. Evgen'eva). Moskva: Russkij âzyk, 1985-1988]

ССРЯ: Словарь синонимов русского языка (ред. А. П. Евгеньева). Москва: Астрель : АСТ, 2007.

[SSRÂ: Slovar' sinonimov russkogo âzyka. (red. A. P. Evgen'eva). Moskva: Astrel' : AST, 2007]

ТСРЯ Уш: Толковый словарь русского языка. T. I - IV (ред. Д. Н. Ушаков). Москва: Государственный институт «Советская энциклопедия», 1935-1940.

[TSRÂ Uš: Tolkovyj slovar' russkogo âzyka. T. I - IV (red. D. N. Ušakov). Moskva: Gosudarstvennyj institut «Sovetskaâ ènciklopediâ», 1935-1940]

ТСРЯ Шв: Толковый словарь русского языка с включением сведений о происхождении слов (ред. Н. Ю. Шведова). Москва: Издательский центр «Азбуковник», 2008.

[TSRÂ Šv: Tolkovyj slovar' russkogo âzyka s vklûčeniem svedenij o proishoždenii slov (red. N. Û. Švedova). Moskva: Izdatel'skij centr «Azbukovnik», 2008]

ФСРЯ: Молотков, А. И. Фразеологический словарь русского языка. Москва: Советская Энциклопедия, 1968.

[FSRÂ: Molotkov, A. I. Frazeologičeskij slovar' russkogo âzyka. Moskva: Sovetskaâ Ènciklopediâ, 1968.]

ФСРЛЯ Фёдоров, А. И. Фразеологический словарь русского литературного языка. Москва: Астрель: АСТ, 2008.

[FSRLIâ: Fëdorov, A. I. Frazeologicheskiī slovar' russkogo literaturnogo iâzyka. 
Moskva: Astrel' : AST, 2008]

Шулежкова, С. Г. Фразеологический словарь старославянского языка: свыше 500 ед. Москва: Флинта Наука, 2011.

[Šuležkova, S. G. Frazeologičeskij slovar' staroslavânskogo âzyka: svyše 500 ed. Moskva: Flinta Nauka, 2011]

ЭСРЯ: Этимологический словарь русского языка: в IV томах (ред. М. Фасмер). Москва: Астрель, 2007.

[ĖSRÂ: Ėtimologičeskij slovar' russkogo âzyka: v IV tomah (red. M. Fasmer). Moskva: Astrel', 2007]

Једнојезични речници српског језика:

EPXCJ: Skok, Petar. Etimologijski rječnik hrvatskoga ili srpskoga jezika. Zagreb: JAZU, 1971.

[ERHSJ: Skok, Petar. Etimologijski rječnik hrvatskoga ili srpskoga jezika. Zagreb: JAZU, 1971]

ФPXCJ: Matešić, Josip. Frazeološki rječnik hrvatskoga ili srpskog jezika (ured. Zvonimir Diklić). Zagreb: Školska knjiga, 1982.

[FRHSJ: Matešić, Josip. Frazeološki rječnik hrvatskoga ili srpskog jezika (ured. Zvonimir Diklić). Zagreb: Skolska knjiga, 1982]

Оташевић, Ђорђе. Фразеолошки речник српског језика. Нови Сад: Прометеј, 2012.

[Otašević, Đorđe. Frazeološki rečnik srpskog jezika. Novi Sad: Prometej, 2012]

РСЈ Вујанић, Милица и др. Речник српског језика. Нови Сад: Матица српска, 2011. [RSJ 2011: Vujanić, Milica i dr. Rečnik srpskog jezika. Novi Sad: Matica srpska, 2011] PCAНУ: Речник српскохрватског књижевног и народног језика. Књига I - XXI. Београд: Институт за српски језик САНУ, 1959.

[RSANU: Rečnik srpskohrvatskog književnog i narodnog jezika. Knjiga I - XXI. Beograd: Institut za srpski jezik SANU, 1959]

PCCJ: Речник синонима (уред. Павле Ћосић). Београд: Корнет, 2008.

[RSSJ: Rečnik sinonima (ured. Pavle Ćosić). Beograd: Kornet, 2008]

\section{Преводни речници:}

Менац, Антица. Русско хорватский или сербский фразеологический словарь. Т. I - II. Загреб: Школска књига, 1979-1980.

[Menac, Antica. Ruscko horvatskij ili serbskij frazeologičeskij slovar'. T. I - II. Zagreb: Školska kњiga, 1979-1980]

PCXС: Станкович, Боголюб. Русско-сербскохорватский словарь: около 52000 слов. Москва: Русский язык; Нови-Сад: Матица српска, 1988.

[RSHS: Stankovič, Bogolûb. Russko-serbskohorvatskij slovar': okolo 52000 slov. Moskva: Russkij âzyk; Novi-Sad: Matica srpska, 1988] 
Прилог 1

Руски примери у којима се уз компоненту чёрт појављује варијантна компонента:

1. за каким (коим) чёртом (дьяволом, лешим) - зашто? којег врага (Ђавола)? За чије бабе здравље?

2. к чёрту (к бесу, к лешему, к шуту, к чёртовой матери, к чёртовой бабушке) - до врага, дођавола, к врагу, к вражјој матери

3. какого чёрта (беса, дьявола, лешего, шута, хрена) - зашто? којег врага (Ђавола)? За чије бабе здравље?

4. ко <всем> чертям (псам, чертям собачьим) - до врага, дођавола, к врагу, к вражјој матери

5. на кой (какой) чёрт (бес, дьявол, шут, леший, пес, ляд, хрен, прах) - зашто? којег врага (Ђавола)? за чије бабе здравље?

6. ни чёрта (ни лешего, ни шиша, ни хрена, ни шута) - ништа, ни врага, ципак

7. чёрт (бес) верёвочкой связал - <сам> враг их је спојио, нашла крпа закрпу

8. ч чёрт (бес, леший, нелёгкая) дёрнул (дёрнула) меня (тебя, его, её, нас, вас, их) за язык - Ђаво га је повукао за језик

9. чёрт (бес, леший, нелёгкая) несёт (принёс) кого - враг га носи (однео, донео)

10. чёрт (бес, леший, нелёгкая) носит кого где - враг га носи (однео, донео)

11. чёрт (бес, леший, шут, пес, хрен, прах) с ним (с тобой, с ней, с вами, с ними) - враг га носи (однео, донео)

12. чёрт (бес, нечистый, нечистый дух, нелёгкая, грех) попутал кого - враг (Ђаво, бес) га је навео (натерао)

13. чёрт (леший, иут, пес, прах) меня (тебя, его, её, нас, вас, их) возьми (дери, побери, подери) - враг га носи (однео, донео)

14. чёрт (леший, иут, пес, прах) меня (тебя, его, её, нас, вас, их) дёрнул - Ђаво (враг итд.) га је натјерао (натентао, навео итд.)

15. чёрт (нелёгкая, нечистая сила) несёт (занёс) кого куда - враг носи (однео, донео) кога куда

16. чёрт (нелёгкая) носит (унёс) кого - враг носи (однео, донео)

17. чёрт (нелёгкая итд.) сунул (угораздил) его жениться (поехать итд.) - који му је враг (Ђаво) био да се оженио (да је отишао), баш (ито) му је <то> требало да се ожени (да оде итд.)

18. что за чёрт (дьявол)! - који је то враг (Ђаво)? шта то значи? види врага!

Руски примери у којима се компонента чёрт појављује као варијантна компонента:

1. бог (господь, аллах, чёрт, бес, леший, иут, пёс, хрен) <его (тебя, её, вас, $u x)>$ знает (ведает) - бог (Ђаво, враг, ко итд.) би га знао, враг (Ђаво, ко итд.) ће га знати

2. бог (господь, аллах, чёрт, бес, леший, пёс) знает - бог (враг, ко) зна, бог (враг, Ђаво, ко) би <га> знао, нико не зна <ко, када>

3. бог (чёрт) знает что - бог (Ђаво, враг, тко итд.) би га знао, враг (Ђаво, тко итд.) ће га знати

4. одному (единому) богу (господу, аллаху, чёрту) - сам бог (враг) зна, ни драги бог не зна, нитко жив не зна

5. известно ну его к богу (аллаху, лешему, чёрту, иуту) (разг.) - бог с њим, нека иде с милим богом, нека га ђаво (враг) носи, нека га вода носи, нека иде дођавола (доврага, бестрага) 


\section{Прилог 2}

Српски примери у којима се уз компоненту враг појављује варијантна компонента или је компонента враг дата као варијантна:

1. бациити што од Ђавола (до врага, к врагу)

2. бежати од кога / од чега као Ђаво од крста (бежати од кога / од чега као враг од свете водице, бојати се (чувати се) од кога / од чега као враг од тамјана)

3. бес (бијес, враг) у те

4. где је Ђаво (враг) рекао лакуноћ

5. доћи ће Ђаво (враг) по своје

6. Ђаво (враг, бес (бијес)) би га знао (ђаво (враг, бес (бијес)) зна, ђаво (враг, бес (бијес)) ће га знати)

7. Ђаво (враг) га (је и сл.) носи (је однео)/ бес (бијес) га (те и др) појела

8. Ђаво (враг) не спава

9. Ђаво (враг) нити оре, нити копа

10. Ђавола (врага) би на леду потковао

11. живи ђаво (враг)

12. и враг (ђаво) зна што је право, али неће да чини (ма неће, него како му је мило)

13. искочити (испасти, скочити, утећи) Ђаволу (врагу) из торбе (из мреже)

14. исти (један) ђаво (враг)

15. истерати ђавола (врага) из кога

16. ићи (отићи) до <сто> ђавола (ићи (отићи, одлетети) до врага (к врагу, по врагу))

17. који Ђаво (кога Ђавола) (који враг, кога врага; који бес (бијес))

18. не да кому Ђаво (враг) мира

19. није Ђаво (враг) тако (онако) ирн (као што га људи сликају (молују))

20. однео враг (Ђаво) шалу

21. отићи к врагу (до ђавола, до беса (бијеса))

22. палити Богу и ђаволу (врагу) свећу

23. патити (мучити се) као Ђаво у плиткој води (као враг на плитку дну)

24. послати кога / што до Ђавола (к врагу, до врага)

25. продати (дати, записати, предати, завештати) душу ђаволу (врагу)

26. ружан као ђаво (враг, грех)

27. с Ђаволом (врагом) тикве сејати (садити)

28. тражити ђавола (врага)

29. тражити Ђавола (врага) <без свеће, са свећом, с лучем>

30. ушао коме Ђаво (шиљати враг) под кожу

31. уиао Ђаво (враг, нечастиви, бес (бијес), сто Ђавола, сто бесова (бијесова)) укога

32. ирн као враг (Ђаво) - јако / посве ирн

33. богу иза леђа (за леђима) (врагу иза леђа (за леђима)) 
Елена Йочич

\title{
НЕСИНОНИМИЧНЫЕ ЛЕКСИЧЕСКИЕ ВАРИАНТЫ КОМПОНЕНТОВ ЧЁРТ И ВРАГ В РУССКИХ И СЕРБСКИХ ФРАЗЕОЛОГИЗМАХ
}

\begin{abstract}
Резюме
В настоящем исследовании проводится сравнительно-сопоставительный анализ лексических вариантов компонентов чёрт и враг в 56 фразеологизмах (23 в русском и 33 в сербском языках). Источниками данного корпусного исследования являются фразеологические и толковые словари русского и сербского языков. В исследовании анализируются несинонимические варианты, т.е. те, которые не регистрируют словари синонимов русского и сербского языков. Данные варианты были проанализированы на лексикографическом, лексикологическом, этимологическом, фразеологическом и лингвокультурологическом уровне. Настоящее исследование было проведено в целях выявления и определения сходств и отличий фразеологических подсистем двух сопоставляемых родственных языков. Результаты анализа показали, что в русском языке количество фразеологизмов с вариантами компонента чёрт меньше, чем количество фразеологизмов с вариантами компонента враг в сербском языке, а также, что в русском языке существует больше вариантов компонента чёрm, чем в сербском языке - вариантов компонента враг (20:7). В корпусе сербских фразеологизмов все варианты являются синонимамы компонента враг (за исключением компонента бог), в то время как в русском языке обнаруживаются синонимы и несинонимы компонента чёрт. Среди несинонимов выделяются те, у которых религиозная коннотация (метонимы: грех и прах), и те, у которых мифологическая (хипонимы: леший, пёс, шиш, шут, эвфемизмы: нелёгкая, хрен, метоним: ляд), ввиду чего изменение образности фразеологизма не обнаруживается. В итоге исследования можно прийти к выводу, что в той части языковой картины мира, которая относится к народным поверьям и религиозному учению о чёрте и враге, русскую и сербскую языковые картины мира можно считать близкими, но не одинаковыми.
\end{abstract}

Ключевые слова: фразеология, вариантность, лексический вариантный компонент, русский, сербский, чёрт, враг. 